ORIGINALNI

ČLANAK

\title{
Contact sports as a sport of more aggressive athletes? Aggressiveness and other psychological characteristics of youth athletes involved in contact and non-contact sports
}

\author{
Kontaktni sportovi kao sportovi agresivnijih \\ sportaša? Agresivnost i druge psihološke \\ karakteristike mladih sportaša koji se bave \\ kontaktnim i beskontaktnim sportovima
}

Nikolina Huđin, Umjetnička udruga „Korak”, Zagreb, Hrvatska

Dragan Glavaš, Hrvatsko katoličko sveučilište, Zagreb, Hrvatska

Mario Pandžić, Hrvatsko katoličko sveučilište, Zagreb, Hrvatska
ABSTRACT

Keywords:

Youth,

Contact sports,

Non-contact

sports,

Aggressiveness
On-field aggressive behaviour is often seen on sports fields and numerous theories tried to identify its origins. This study tackled the question of whether the youth athletes in contact and non-contact sports could be differentiated on the basis of the hostile and competitive aggression, and some other characteristics that showed to be related to the aggressive onfield behaviour. The study sample comprised 154 of ( $51 \%$ girls) young athletes aged between 10 and 15 years from various contact and non-contact disciplines (wrestling, boxing, taekwondo, football, swimming, athletics, and dance). Participants completed several questionnaires regarding their aggressive behaviour, motivation, anxiety, self-esteem and emotional regulation. Only the competitive, but not hostile, aggression was more present among the youth athletes in contact sports. From all other characteristics, self-esteem, although in a lower extent, predicted affiliation of the non-contact sports group. 
Huđin, N., Glavaš, D., Pandžić, M. - Contact sports as a sport of more aggressive athletes?

2020. Fakultet za sport i turizam, Novi Sad, Tims.Acta 14, 5-16

\begin{tabular}{|c|c|}
\hline $\begin{array}{r}\text { Ključne reči: } \\
\text { mladi, } \\
\text { kontaktni sportovi, } \\
\text { beskontaktni } \\
\text { sportovi, } \\
\text { agresivnost }\end{array}$ & $\begin{array}{l}\text { Agresivno ponašanje često se može primijetiti na sportskim terenima, a brojne su teorije } \\
\text { pokušale utvrditi njegovo podrijetlo. Ovo istraživanje bavilo se pitanjem mogućnosti razlikovanja } \\
\text { mladih sportaša uključenih u kontaktne i beskontaktne sportove na temelju neprijateljske i } \\
\text { natjecateljske agresije, te nekih drugih karakteristika za koje se pokazalo da su povezane sa } \\
\text { agresivnim ponašanjem na terenu. U uzorak su uključena } 154 \text { (51\% djevojčica) mlada sportaša } \\
\text { u dobi između } 10 \text { do } 15 \text { godina iz različitih kontaktnih i beskontaktnih disciplina (hrvanje, boks, } \\
\text { taekwondo, nogomet, plivanje, atletika i ples). Sudionici su ispunili nekoliko upitnika vezanih } \\
\text { uz agresivno ponašanje, motivaciju, anksioznost, samopoštovanje i emocionalnu regulaciju. } \\
\text { Samo je natjecateljska, ali ne i neprijateljska, agresija bila prisutnija kod mladih sportaša koji se } \\
\text { bave kontaktnim sportovima. Od svih ostalih karakteristika samopoštovanje je, iako u manjem } \\
\text { opsegu, predviđalo pripadnost skupini beskontaktnih sportova. }\end{array}$ \\
\hline
\end{tabular}

TIMS Acta (2020) 14, 5-16

\section{Introduction}

The benefit of sport activities on a child's physical and mental health is well known. Besides positive effects on physical and biomechanical development, the effects on habit development, self-esteem, emotional regulation, anxiety are also proven (Lane \& Lovejoy, 2001; Manger \& Motta, 2005; Szuhany, Bugatti, \& Otto, 2015).

However, the diversity of sports necessarily points to the interplay between various sports and individual psychological characteristics. Furthermore, an interesting and theoretically relevant question is whether some psychological characteristics of young athletes involved in contact and non-contact sports differ. Intuitively posed hypothesis on possibly higher aggressiveness of youth athletes involved in contact sports in comparison to their non-contact sports peers has received significant attention from the scientific and professional community.

The classic study of Zillman, Johnson and Day (1974) found no differences in aggressiveness between noncontact and contact sports university athletes under conditions of no provocation. Still, while being provoked by an insult given by the second experimenter which was heard over the open intercom, non-contact sport athletes behaved significantly less aggressively than contact sports athletes. The authors discussed those results as the challenge for learning theories, such as social learning theory (Bandura, 1973), emphasizing that aggressiveness in contact-sport athletes failed to exceed in other conditions. Additionally, the results questioned the selection hypothesis and the view of contact sports as an outlet for strained hostilities.

Another seminal study found increased aggression over the season among university football players but not among physical education students (Patterson, 1974). In line with this evidence, Trulson (1986) showed increased aggressiveness and delinquency tendency among youth martial arts athletes while Anderson (1999) showed higher aggressiveness of adolescent karate athletes in comparison to baseball and basketball athletes.

More recent studies also indicated the relation between contact sport participation and aggressive behaviour (Malinauskas, Dumiciene, \& Malinauskiene, 2014; Trivedi \& Pinot, 2005) and an increase in youth athletes' perception of the legitimacy of aggressive sport behaviour (Conroy, Silva, Newcomer, Walker, \& Johnson, 2001). Research on athletes' aggressiveness has been extended on off-field aggression as well. Benedict and Yaeger (1998) provided intriguing data on the large sample $(\mathrm{N}=509)$ of NFL players, with the one-fifth of them being arrested because of different crimes such as rape, family abuse, murder, or physical assault. Endresen and Olweus (2005) empirically supported this data. The results of their research showed elevated levels of violent and non-violent antisocial behaviour after two years of participation in "power sports" such as comprising boxing, weightlifting, wrestling, and martial arts. Potential support for this view was increased anger and aggressiveness of contact and collision sports athletes with higher athletic identity as the degree of identification with the athlete role (Visek, Watson, Hurst, Maxwell, \& Harris, 2010). That evidence supported the assumption of social learning theory and the developmental hypothesis of higher offfield aggression as a result of contact sports involvement and was in line with the cognitive-neoassociation theory of aggression suggesting potential activation of adopted aggressive reactions by the environmental cues and stimuli (Berkowitz, 2012). Also, the results indicated the possibility of contact sports being more attractive to more aggressive athletes, as proposed by the selection hypothesis. These findings also led to the widely 
Huđin, N., Glavaš, D., Pandžić, M. - Contact sports as a sport of more aggressive athletes?

2020. Fakultet za sport i turizam, Novi Sad, Tims.Acta 14, 5-16

accepted belief that higher aggressiveness characterises contact sports athletes in comparison to non-contact sports athletes (Cox, 2005; Singer, 1975).

However, the evidence is not unambiguous. Skelton, Glynn and Berta (1991) found the same level of aggressiveness for children who trained taekwondo and their peers not involved in sports. More recent studies supported the possibility of no higher level of aggressiveness of contact sports athletes. Keeler (2007) found no differences in general aggression, and hostile and instrumental sport aggression between contact, collision and non-contact sport athletes. Similarly, the same level of aggressiveness among athletes from various contact and non-contact sports was found in the study of Reza (2012). Pačesová and Šmela (2020) also showed the same level of physical and verbal aggression, as well as anger among contact and non-contact sport athletes, while the study of Boostani, Boostani and Nowzari (2012) showed higher aggressiveness only with kickboxing athletes but not for other contact sport athletes. It is important to note that these studies comprised students and early adulthood participants which calls into caution the conclusion about this effect being present among children and youth athletes for which the empirical insights are scarce. That is even more prominent given the theoretically possible positive effects of sport involvement on behaviour manifestations. In that line, Daniels and Thornton (1990) even found decreased hostility after the period of fighting sports training, while Kotarska, Nowak, SzarkEckardt and Nowak (2019) showed positive correlations between practising contact sport and healthy behaviour. Those positive effects of involvement in contact sport are explained by the frustration-aggression hypothesis (Eron, 1994) and displacement catharsis theory (Bushman, Baumeister, \& Phillips, 2001; Geen \& Quanty, 1977). On the other hand, above-mentioned Anderson's (1999) research, despite showing a higher level of aggressiveness of youth karate athletes in comparison to basketball and baseball athletes, found no increase or decrease of aggressiveness during the period of karate training. An appropriate sports reward system for positive and conventional reactions and the adoption of general positive sports principles, highlighted within the more recent social-cognitive theory (Bandura, 1999; 2005) and sport-for-development theory (Lyras \& Peachey, 2011) may explain these findings.

Discrepant evidence of aggressiveness among contact and non-contact sports athletes clearly highlights the complexity of this research question. It may be due to the fact that other important psychological characteristics can contribute to the level of aggressiveness in sport, where this interplay may be different in contact versus non-contact sports. More specifically, a prior research in the field of sport psychology pointed to the conclusion that individual differences in emotional regulation, motivation, self-esteem, as well as anxiety can shape the extent of aggressive behaviour in sports context. Emotional regulation implies the use of self-regulatory processes in which individuals consciously or unconsciously control the emotions that arise and develop strategies to either modify those emotions into acceptable ones or show them as they are (if this is acceptable at the moment). It is very much purposeful and functional given that with adequate emotional responses the athlete can increase his strength, improve interaction and relationship with teammates and the coach, reduce the risk of losing control in stressful situations, as well as the likelihood of injury (Lane, Beedie, Jones, Uphill, \& Devonport, 2012). Having said that, emotional regulation, or lack-there-off, can be of high importance when it comes to the behaving aggressively on the sports pitch. Gano-Overway et al. (2009) conducted a study on children involved in certain sports activities. The results showed that individuals who better regulate their emotions exhibit more prosocial behaviours, while a weaker ability to self-regulate was a strong predictor of aggressive behaviour. Being involved in sports activity can also lead to the development of other competencies, new attitudes and perceptions, which can have a positive impact on self-esteem mainly mediated through children's sports self-image (Slutzky \& Simpkins, 2009). On the other hand, it is plausible to hypothesise that sports youngsters, who did not reach satisfying levels of self-esteem, could behave more aggressively on the field. Going back to the literature, studies examining the relationship between self-esteem and aggressive behaviour in children within a sports context are evidently scarce, to say the least. However, some studies (e.g. Donnellan, Trzesniewski, Robins, Moffitt, \& Caspi, 2005) conducted on the general population of children indicated a negative correlation of aggressiveness (subscale of delinquent behaviour) and self-esteem. Hence, it could be possible that this relationship is also present in young athletes as well. Furthermore, in sports, just like in other areas of life, players' motivation can be intrinsic (internal) and extrinsic (external). It is clear that every athlete out there has both intrinsic and extrinsic motives for crafting their skills that lead them to higher overall performance. What distinguishes them is the different ratio of the two, i.e. intrinsically motivated 
athletes have extrinsic motives as well, but in a much lesser extent, and extrinsically motivated athletes also have a particular, small part of intrinsic motivation. In athletes, intrinsic motivation is highly significant because it ensures perseverance in moments of defeat, loss and injury, and at the same time moves them to be more effortful on daunting practice sessions (Cox, 2005). On the opposite side, lack of intrinsic motivation, just as low self-esteem, and poor emotional regulation, may lead to aggressive sport behaviour. Chantal, Robin, Vernat and Bernache-Assollant (2005) found, albeit not on young athletes but older student and club players, that higher the self-determination, such as intrinsic motivation, the less frequent aggressive behaviour occurred. Also, athletes who predominantly had high scores on the autonomy scale manifested more fair-play behaviours (e.g. avoiding illegal behaviour, respecting referees, opponents, and coaches) compared to low-autonomy athletes, even in highly competitive situations.

Besides aforementioned psychological characteristics, anxiety has also shown to co-occur with different types of aggressive behaviours, e.g. reactive aggression (Fite et al., 2010), in more general studies outside sport psychology context. Kunimatsu and Mersee (2012) argue that this may be due to the disfunction of a broader fight-orflight system where variations in cognitive (i.e. negative thoughts) or emotional mechanisms (i.e. emotional regulation/reactivity) that underly fight-or-flight responses may increase the probability of aggression, anxiety, or both when dealing with threatening stimuli in the environment. Prior sport psychology studies on athletes also gave empirical support for the aggressionanxiety linkage. Gümüşdağ (2013) found an association between somatic anxiety and both passive and hostile aggression among professional football players, while Pačesová and Šmela (2020) also showed a significant relationship between athletes' anxiety trait level and physical aggression. Besharat \& Ghiabi (2012) argue that losing attention to the task in athletes often leads to failure intensifying their anger that can undermine their concentration and performance where fear and anxiety about failure may rise to the surface and cause aggressive behaviour.

Given inconsistent empirical evidence on aggressiveness as a distinctive characteristic of youth contact and noncontact athletes, as well as other relevant characteristics that may interplay in sports contexts, the purpose of our study was to investigate which psychological characteristics differentiate youth athletes of those two types of sports. Besides general aggressive behaviour, and competitive aggressiveness and anger, we also measured emotional regulation, motivation, self-esteem, and sport anxiety given that those characteristics have the potential to shape the level of aggressive behaviour of young athletes and this interplay could be important in distinguishing contact and non-contact sports groups. To control intercorrelations among observed variables and estimate their effect, we employed logistic linear regression model with the enter method, given the lack of more comprehensive theoretical framework which would call for the hierarchical approach.

\section{Method}

\section{Participants}

A total of 154 male $(N=75)$ and female $(N=79)$ youth athletes $\left(M_{\text {age }}=13,49, S D_{\text {age }}=1,46\right.$, range $\left.10-15\right)$ participated in the study. All participants were involved in organized training in contact: wrestiling $(N=17)$, boxing $(N=21)$, taekwandoo $(N=31)$ and football $(N=7)$, and non-contact sports: swimming $(N=29)$, athletics $(N=$ 26) and dance $(N=23)$.

\section{Instruments}

The revised version of the Buss-Perry Aggression Questionnaire

The revised 27 item version of the Buss-Perry Aggression Questionnaire (Buss \& Perry, 1992) was used to measure aggressive behaviour. Participants rated all items using a 5 -point scale (from $1=$ completely true for me to $5=$ completely false for me). The result was formed as a simple linear combination of items where higher result indicates higher aggressiveness. Internal consistency coefficient $(a=0,85)$ indicated high reliability of the scale.

\section{The Competitive Aggressiveness and Anger Scale}

The Competitive Aggressiveness and Anger Scale (CAAS; Maxwell \& Moores, 2007) consists of 12 items. Responses are given on a five-point scale (from $1=$ almost never to 5 = almost always). The overall score on the scale was formed by summing the scores on all items where higher result indicates a higher competitive aggressiveness and anger. The scale showed to be highly reliable $(a=0,85)$. 
Huđin, N., Glavaš, D., Pandžić, M. - Contact sports as a sport of more aggressive athletes?

2020. Fakultet za sport i turizam, Novi Sad, Tims.Acta 14, 5-16

The revised Sport Motivation Scale

Revised Sport Motivation Scale (SMS-2; Pelletier, Rocchi, Vallerand, Deci \& Ryan, 2013) is an 18-item inventory comprised of six three-item subscales: intrinsic motivation, integrated regulation, identified regulation, introjected regulation, external regulation and motivation, representing the multifaceted dimensions inherent within self-determination theory. Participants rated the items using a seven-point Likert scale (from 1= does not correspond at all to 7 = corresponds completely). Results of exploratory factor analysis didn't support theoretically assumed six-factor solution since a high proportion of items was saturated by multiple factors. For that reason, the overall result was calculated for intrinsic motivation factor since it had a clear structure, that is, items that measured intrinsic motivation had low loadings on all other factors. Internal consistency coefficient for intrinsic motivation subscale was $a=0,86$. The extrinsic motivation was calculated in line with validation results on revised SMS-2. Internal consistency coefficient of this subscale was $\alpha=0,61$.

\section{The Sport Anxiety Scale}

The Sport Anxiety Scale-2 (SAS-2; Smith, Smoll, Cumming, \& Grossbard, 2006) contains 15 items. Items are rated on a four-point scale, where 1 stands for "none at all", and 4 for "very much". Results are formed by summing the participants' estimates on all items, where higher score indicates a higher level of general sports anxiety. The reliability of the scale was acceptable ( $a=$ 0,69 ). The questionnaire was translated into Croatian, and only the total score on the scale was used in this paper.

\section{Emotion Regulation Questionnaire}

Emotion Regulation Questionnaire (ERQ; Gross \& John, 2003) has ten items which measure children's tendency to regulate their own emotions by cognitively reappraising or suppressing them. Participants rated each item on a seven-point scale from 1 (strongly disagree) to 7 (strongly agree). The questionnaire has two subscales. Cognitive reappraisal with items such as "I control my emotions by changing the way I think about the situation I'm in", and Expressive suppression with the example of an item "I keep my emotions to myself". The overall result was calculated separately for each subscale by summing the participants' estimates for each item in the corresponding subscale. The higher result on each subscale indicates more frequent use of that emotion regulation strategy. Cronbach alpha coefficient of internal consistency for the whole questionnaire was $a=$ 0,63 , for Cognitive reappraisal subscale $a=0,60$ and for Expressive suppression subscale $a=0,59$.

\section{Rosenberg self-esteem scale}

Rosenberg self-esteem scale (Rosenberg, 1965) measures global self-esteem. It is a ten-item measure, where five items are formulated in the positive and five in the negative direction. Participants rated each item on a 4-point scale (from 1 = strongly disagree to 4 = strongly agree). Internal consistency coefficient of the scale was $a=0,70$.

\section{Procedure}

The manager of each sport club that was involved in the research was first contacted by the phone. After getting their permission, every child in the club was given a plea to participate in the research, informed consent, as well as the study questionnaires. They were assured that the collected data will be completely anonymous, as well as that participation in the research is voluntary and that they do not have to participate if they or their parents decide so. Children filled out the questionnaires and signed informed consent (which had to be approved by the children's parents also), at the comfort of their home. Completed questionnaires and signed informed consents were returned by the children to the sports club coaches in the sealed envelopes. Data collection lasted from June to October 2018. For all the measuring instruments used in this research, consents were obtained from their respective authors.

\section{Results}

Table 1 shows descriptive data on the psychological characteristics of youth athletes involved in contact and non-contact sports and the characteristics of distributions. Prior to testing, we detected for possible outliers. Along with the visual inspection, to test the distributions for outliers, we used z-scores and outlier labelling rule (Hoaglin, Iglewicz, \& Tukey, 1986). Results with absolute $z$-scores higher than 3,3 and outside the outlier labelling rule intervals were characterised as outliers $(\mathrm{N}=3)$. 
Huđin, N., Glavaš, D., Pandžić, M. - Contact sports as a sport of more aggressive athletes? 2020. Fakultet za sport i turizam, Novi Sad, Tims.Acta 14, 5-16

Table 1. Descriptives on psychological characteristics of youth athletes involved in contact and non-contact sports

Sports

\begin{tabular}{|c|c|c|c|c|c|c|c|c|}
\hline & \multicolumn{2}{|c|}{ Contact } & \multicolumn{6}{|c|}{ Non-contact } \\
\hline & $M(S D)$ & $T R$ & $M(S D)$ & $T R$ & KS & Skewness & Kurtosis & $t$ \\
\hline Agresiveness & $61,65(16,75)$ & $28-98$ & $68,01(17,75)$ & $34-99$ & 0,08 & 0,41 & $-0,55$ & $-2,26 *$ \\
\hline $\begin{array}{l}\text { Competitive } \\
\text { Agressiveness and Anger }\end{array}$ & $25,06(7,41)$ & $19-49$ & $20,95(7,13)$ & $12-44$ & $0,13 *$ & 0,81 & 0,00 & $-3,44 * *$ \\
\hline Cognitive reappraisal & $27,91(7,84)$ & $7-42$ & $30,94(6,92)$ & $11-42$ & 0,11 * & $-0,82$ & 0,40 & $2,5^{*}$ \\
\hline Expressive supression & $15,12(4,91)$ & $4-25$ & $15,82(4,85)$ & $5-25$ & $0,11 *$ & $-0,27$ & $-0,49$ & 0,85 \\
\hline Intrinsic motivation & $62,54(10,55)$ & $37-77$ & $63,22(8,69)$ & $31-77$ & $0,12 *$ & $-1,02$ & 0,89 & $-0,43$ \\
\hline Extrinsic motivation & $14,39(1,46)$ & $10-18$ & $13,96(1,97)$ & $10-18$ & 0,23 & $-0,69$ & 0,22 & $-1,52$ \\
\hline Self esteem & $31,97(4,15)$ & $18-39$ & $33,55(4,15)$ & $19-40$ & $0,12 *$ & $-0,70$ & 0,74 & $2,4 *$ \\
\hline Sport anxiety & $28,85(9.04)$ & $15-47$ & $27,88(6,83)$ & $16-47$ & 0,08 & 0,53 & $-0,40$ & $-0,75$ \\
\hline
\end{tabular}

Note. TR-Total rang, KS-Kolmogorov-Smirnov test, **p $<0,01, * \mathrm{p}<0.05$

To assess the normality of data distributions, we used the Kolmogorov-Smirnov test. Data for aggressiveness and sport anxiety were distributed normally. A significant Kolmogorov test indicated that the distributions of competitive aggressiveness and other psychological characteristics observed were significantly different from a normal distribution $(p<0,05)$. However, P-P plots and values of skewness and kurtosis ranging from -1 to 1 (except for slightly lower skewness of Intrinsic motivation distribution), did not pose a threat to the assumptions and robustness of logistic regression model used (Field, 2013).

Variances of observed variables were stable and homogenous across groups of contact and non-contact athletes. The univariate testing suggested higher general aggressiveness and competitive aggressiveness and anger, and lower self-esteem and cognitive reappraisal of youth athletes involved in contact sports in comparison to their peers involved in non-contact sports. Other psychological characteristics were equally manifested in both groups of athletes.

Table 2 shows the Pearsons correlation coefficients between the observed predictors. General aggressiveness moderately (+) correlated with competitive aggressiveness and anger $(r=0,60)$. Aggressiveness was positively, yet less strongly, correlated with sport anxiety $(r=0,35)$. Sport anxiety was also shown to be slightly positively correlated with competitive aggressiveness and anger $(r=0,19)$ and negatively with self-esteem $(r=$ - 0,42). Self-esteem was also slightly $(+)$ correlated with intrinsic motivation $(r=0,25)$. The low positive correlation was found between cognitive reappraisal and expressive suppression $(r=0,17)$, cognitive reappraisal and intrinsic motivation $(r=0,26)$ and between cognitive reappraisal and self-esteem $(r=0,24)$.

The absence of the high correlations among observed predictors indicated the absence of multicollinearity. Additionally, multicollinearity was tested using VIF and Tolerance statistics. The average VIF ( $M=1,36$, ranging from 1,05 to 1,70 ) and tolerance indicators higher than 0,58 (ranging from 0,58 to 0,95 ) confirmed the absence of multicollinearity issue between predictors.

The results of binary logistic regression showed a significant model suggesting the possibility to predict involvement in youth contact and non-contact sports by the observed predictors $(\chi 2(7)=21,321, p<0.05)$. 
Huđin, N., Glavaš, D., Pandžić, M. - Contact sports as a sport of more aggressive athletes?

2020. Fakultet za sport i turizam, Novi Sad, Tims.Acta 14, 5-16

Table 2. Intercorrelations among observed psychological characteristics

\begin{tabular}{|c|c|c|c|c|c|c|c|c|}
\hline & 1 & 2 & 3 & 4 & 5 & 6 & 7 & 8 \\
\hline Aggressiveness (1) & 1 & $60^{* *}$ &,- 08 & 03 & 03 &,- 02 &,$- 20^{*}$ &, $35^{* *}$ \\
\hline Competitive Aggressiveness and Anger (2) & & 1 &,- 13 &,- 07 &,- 04 &,- 07 &,- 15 &, $19^{*}$ \\
\hline Cognitive reappraisal (3) & & & 1 &, $17^{*}$ &, $26^{* *}$ &,- 04 &, $24^{* *}$ &,- 01 \\
\hline Expressive suppression (4) & & & & 1 & 07 & 02 & 01 &,- 06 \\
\hline Intrinsic motivation (5) & & & & & 1 &,- 02 &, $25^{* *}$ &,- 03 \\
\hline Extrinsic motivation (6) & & & & & & & 07 &,$- 17^{*}$ \\
\hline Self-esteem (7) & & & & & & & 1 &,$- 42^{* *}$ \\
\hline Sport anxiety (8) & & & & & & & & 1 \\
\hline
\end{tabular}

Note. $* * p<0,01, * p<0.05$

Table 3. Unstandardized logistic regression coefficients and odds ratios

\begin{tabular}{|c|c|c|c|c|c|}
\hline & \multirow{2}{*}{ B } & \multirow{2}{*}{ S.E. } & \multirow{2}{*}{ Odds ratio } & \multicolumn{2}{|c|}{ 95\% C.I. for Odds ratio } \\
\hline & & & & Lower & Upper \\
\hline Aggressiveness & $<0,01$ & 0,01 & 1,00 & 0,98 & 1,03 \\
\hline Competitive Aggressiveness and Anger & $0,08 *$ & 0,03 & 1,08 & 1,01 & 1,15 \\
\hline Cognitive reappraisal & $-0,02$ & 0,02 & 0,95 & 0,92 & 1,00 \\
\hline Expressive suppression & $-0,02$ & 0,04 & 0,98 & 0,93 & 1,06 \\
\hline Intrinsic motivation & 0,01 & 0,01 & 1,03 & 0,98 & 1,07 \\
\hline Extrinsic motivation & 0,02 & 0,01 & 1,02 & 0,97 & 1,04 \\
\hline Self esteem & $-0,08 *$ & 0,05 & 0,90 & 0,84 & 1,00 \\
\hline Sport anxiety & $<0,01$ & 0,01 & 1,00 & 0,98 & 1,03 \\
\hline
\end{tabular}

Note. Contact athlete group was coded with 1. R2 = 0.133 (Cox \& Snell), 0.179 (Nagelkerke), $\star p<0.05$

Binary logistic regression coefficients, that is unstandardized logistic regression coefficients (B) and odds ratios, are presented in Table 3 . The results indicated that the observed predictors explained from 13,3 to $17,9 \%$ of the variance of contact and non-contact group differ. More precisely, competitive aggressiveness and anger were shown to be more present in contact sport athletes, while self-esteem characterised non-contact sports athletes. Other predictors did not significantly explain the difference between contact and non-contact athletes. The odds ratio showed that a one-unit increase (B) of competitive aggressiveness and anger led to the $8 \%$ increase in the odds for belonging to the group of contact sports athletes. On the other hand, the odds ratio for self-esteem showed $8 \%$ of increased probability for belonging to the group of non-contact athletes with one-unit increase in the unstandardized coefficient. The results of binary logistic regression showed the univariate discriminative effect of general aggressive behaviour as the result of its correlation with competitive aggressiveness and anger. The overall percentage of correctly classified cases in the contact and non-contact group in the regression model increased from the initial $55,7 \%$ to $69,1 \%$.

Additionally, given that football is arguably different from other contact sports in our study, and given the small 
Huđin, N., Glavaš, D., Pandžić, M. - Contact sports as a sport of more aggressive athletes?

2020. Fakultet za sport i turizam, Novi Sad, Tims.Acta 14, 5-16

number of football athletes included in our sample, we performed additional analyses without the football players. The results showed the same, unchanged effects confirming the stability of the results with excluded football players.

\section{Discussion}

The purpose of this study was to investigate which psychological characteristics differentiate contact and non-contact youth athletes. We tested the hypothesis of higher aggressiveness of youth contact sports athletes in comparison to youth athletes involved in noncontact sports. The results showed higher competitive aggressiveness and anger, butnotgeneral aggressiveness, of contact sports athletes in comparison to non-contact sports athletes. More specifically, aggression, measured by Buss and Perry (1992) inventory that includes hostile behaviours, was not higher in the group of youth contact sports athletes. The data supported findings of increased competitive aggressiveness due to the sport-specific tasks (Anderson, 1999; Trulson, 1986, Visek et al., 2010), although the effect was not substantial (i.e. small increase of odds ratio).

On the other hand, data seem to contrast the selection hypothesis which suggests that youth athletes with higher general aggressiveness are more likely to engage in contact sports and the developmental hypothesis that assumes adoption and transfer of more aggressive and deviant behaviour outside of the sport (for a review see Beckmann \& Elbe, 2005). According to our results, a more plausible explanation for contact sport athletes having higher competitive, but not general aggressiveness is the effect of vicarious learning and modelling in sportspecific situations as proposed by social learning theory (Bandura, 1973). However, social learning theory principles cannot explain the absence of the higher offfield aggressiveness of contact sports athletes. More closely, our results did not support the assumption that modelled competitive aggressive behaviour leads to the adoption of general aggressive behaviour patterns as a product of sport-specific actions and consequently results in more frequentlz provoked aggressiveness off the sports field, in the 'real world'. Results also contrast cognitive-neoassociation theory of aggression (Berkowitz, 2012) that assumes activation of adopted aggressive reactions (thoughts, feelings, and actions) automatically by the cues and stimuli in the environment. For a more prominent theoretical explanation of higher competitive, but not general aggressiveness of contact sports youth athletes, we could turn to catharsis, social and social cognitive theories. According to the catharsis theory, contact sport-specific tasks may serve as catharsis environment for youth athletes which decreases their general aggressiveness. In our study, this rationalisation would assume a higher general aggressiveness of contact sports athletes before involvement in sports training which is then decreased by the involvement in contact sports. However, this is less likely, and other explanations must be considered. The social and social cognitive theoretical frameworks highlight the positive socialisation and cognitive processes related to sports training. According to social-cognitive theory (Bandura 1999; 2005), sports involvement activates a reward system that reinforces positive and conventionally accepted attitudes, thoughts and behaviours and may serve as a new environment for the exercise of self-efficiency and effective behaviour patterns. This assumption is supported within the more recent sport-for-development theory (Lyras \& Peachey, 2011) that emphasises the positive effects of general sports principles for both individual and social growth. Thus, the positive effect of the participation in whether contact or non-contact sports may strengthen appropriate behaviour patterns without negative effects of contact sports training.

Higher self-esteem is one of those positive effects that have substantial empirical confirmation (e.g. Megakli, Vlachopoulos, Thogersen Ntoumani, \& Theodorakis, 2017; Standage \& Gillison, 2007). However, it is less clear whether self-esteem of contact and non-contact athletes differs. Our findings on higher self-esteem of non-contact in comparison to contact sports athletes are in line with the results of the study of Bojanić, Nedeljković, Sakan, Mitić, Milovanović and Drid (2019), and supported by the potential link between self-esteem and externalising problems such as aggression (Donnellan et al., 2005). Bojanić et al. (2019) showed higher self-esteem of team sports athletes in comparison to combat sports athletes. These results may contrast findings on higher selfesteem of individual sports athletes than team sports athletes (Ali, Ichraf, Khaled, Liwa, \& Ali, 2013), or findings of no differences between individual and team sports athletes (Malinauskas \& Akelaitis, 2018). Bojanić et al. (2019) offered a possible explanation for this finding indicating that social influence determines self-esteem, and that team sport athletes receive more support from the teammates. This explanation may partially fit our result given that about one-third of non-contact 
athletes were involved in dance for which group support is more typical. Nonetheless, a small number of soccer players in our study were characterised as contact sport athletes, and at the same time, athletes involved in swimming and athletics as predominantly individual sports were characterised as non-contact sport athletes, which necessarily aggravates the confirmation of social influence hypothesis. Other reasons for this effect may lie in sports success and perfectionism (Gotwals, Dunn, \& Wayment, 2003; Koivula, Hassmén, \& Fallby, 2002) physical appearance and physical competence (Bowker, 2006) or body image and self-efficacy (Ouyang et al., 2019) which opens an avenue for further empirical endeavours on the interplay of these characteristics and involvement in contact and non-contact sports.

To sum it up, our results add to the existing knowledge of potential differences between youth athletes involved in contact and non-contact sports. They support both theoretical and empirical notion that suggests no firm connection between involvement in contact sports and aggressiveness outside the sports, indicating that contact sports do not necessarily attract youth athletes with different psychological characteristics. Besides competitive aggressiveness and anger, we found only self-esteem as a slightly distinctive characteristic of youth athletes involved in these two types of sports. Further, higher competitive aggressiveness and anger of contact sports athletes suggest that specific sports could result in more frequent aggressive behaviours in a competitive sports environment.

From a theoretical perspective, few important questions are yet to be explored. First, do some characteristics still determine the choice of contact sports athletes? Second, which characteristics of youth athletes are prone to the effect of sport-specific environment and tasks and change as a result of it? Finally, and arguably most important, which mechanism mediates or moderates the possible impact of adopted behaviours in sports, and their transfer in the sport-specific and off-sports environment?

In our attempt to gain new insights related to these questions, we strived to resolve some earlier methodological concerns by including both competitive and general aggressiveness as well as other relevant psychological factors. However, our study has some limitations that future research should address. Though the sample size allowed us to detect some effects, for testing individual predictions in regression, a large sample size is essential. According to some rule of thumb, the research with eight predictors and a mediumsize relationship between predictors and criteria should include around 150 cases (Green, 1991). Our sample size met that criteria but limited the power of design to detect more subtle effects. A related limitation of our study was the subsample of football athletes $(\mathrm{N}=7)$ which we characterised as a contact sports sample. However, the analysis with excluded football athletes revealed the same effects.

The perspective for the future empirical work is the emphasis on other relevant characteristics such as athletes' sport and cultural identity (Visek et al., 2010), as well as physical characteristics (Lemieux, McKelvie, \& Stout, 2002). Finally, a longitudinal research design with the insights on aggressiveness and other relevant characteristics at the beginning of and during sports training will allow understanding patterns of thoughts, feelings and actions and grasping the sources of potential changes in the function of active sports training.

\section{Conclusion}

This study showed that sport-specific competitive aggressiveness was more typical for contact sports athletes while off-field aggressiveness did not differentiate contact and non-contact youth athletes. Self-esteem was higher in non-contact sports athletes, while the other observed characteristics did not statistically predict sports group affiliation. The results challenged the theoretical view of contact sports being more attractive for aggressive youth athletes and the belief of transfer of aggressive behaviour pattern outside of sports. It seems that most psychological characteristics are not dependent on sports type, and that right training approach, independent of sports type, models appropriate behaviours on and off-sports ground.

\section{STATEMENT}

In their statements, the authors confirmed the absence of any conflict of interest. 
Huđin, N., Glavaš, D., Pandžić, M. - Contact sports as a sport of more aggressive athletes?

2020. Fakultet za sport i turizam, Novi Sad, Tims.Acta 14, 5-16

\section{REFERENCES}

Ali, B. M., Ichraf, A., Khaled, T., Liwa, M., \& Ali, E. (2013). Effect of gender and type of sport practiced on aggression and selfesteem in Tunisian athletes. IOSR Journal of Humanities and Social Science, 8(4), 74-80.

Anderson, C. M. (1999). The effects of martial arts training with latency age children. (Doctoral dissertation, University of South Carolina).

Bandura, A. (1973). Aggression: A social learning analysis. Englewood Cliffs, NJ: Prentice-Hall.

Bandura, A. (1999). A social cognitive theory of personality. In Pervin, L., John, (Eds.), Handbook of personality (2nd ed. pp.154-196). New York: Guilford.

Bandura, A. (2005). The Evolution of Social Cognitive Theory. In K. G. Smith, \& M. A. Hitt (Eds.) Great Minds in Management (pp. 9-35). Oxford: Oxford University.

Beckmann, J., \& Elbe, A. M. (2015). Sport psychological interventions in competitive sports. Cambridge Scholars Publishing.

Benedict, J., \& Yaeger, D. (1998). Pros and cons: The criminals who play in the NFL. New York: Warner Books.

Berkowitz, L. (2012). A cognitive-neoassociation theory of aggression. In P. A. M. Van Lange, A. W. Kruglanski, \& E. T. Higgins (Eds.) Handbook of theories of social psychology (pp. 99-117). Thousand Oaks, CA.: Sage Publications.

Besharat, M. A., \& Ghiabi, B. (2012). Anger and aggression in contact and non-contact sports. Comprehensive Psychology, 1(9), 1-7.

Bojanić, Z., Nedeljković, J., Šakan, D., Mitić, P. M., Milovanović, I., \& Drid, P. (2019). Personality traits and self-esteem in combat and team sports. Frontiers in Psychology, 10(2280), 1-6.

Boostani, M. A., Boostani, M. H., \& Nowzari, V. (2012). Investigation and comparison of aggression in athletes in non-contact (swimming), limited contact (karate) and contact (kickboxing) sports. Ido Movement for Culture. Journal of Martial Arts Anthropology, 12(3), 1-4.

Bowker, A. (2006). The relationship between sports participation and self-esteem during early adolescence. Canadian Journal of Behavioural Science/Revue canadienne des sciences du comportement, 38(3), 214-229.

Bushman, B. J.,Baumeister, R. F., \& Phillips, C. M. (2001). Do people aggress to improve their mood? Catharsis beliefs, affect regulation opportunity, and aggressive responding. Journal of personality and social psychology, 81(1), 17-32.

Buss, A. H., \& Perry, M. (1992). The aggression questionnaire. Journal of personality and social psychology, 63(3), 452-459.

Chantal, Y., Robin, P., Vernat, J. P., \& Bernache-Assollant, I. (2005). Motivation, sportspersonship, and athletic aggression: a mediational analysis. Psychology of Sport and Exercise, 6(2), 233-249.

Conroy, D. E., Silva, J. M., Newcomer, R. R., Walker, B. W., \& Johnson, M. S. (2001). Personal and participatory socialisers of the perceived legitimacy of aggressive behavior in sport. Aggressive Behaviour: Official Journal of the International Society for Research on Aggression, 27(6), 405-418

Cox, R.H. (2005). Psihologija sporta. Jastrebarsko: Naklada Slap.

Daniels, K., \& Thornton, E. W. (1990). An analysis of the relationship between hostility and training in the martial arts. Journal of Sports Sciences, 8(2), 95-101.

Donnellan, M. B., Trzesniewski, K. H., Robins, R. W., Moffitt, T. E., \& Caspi, A. (2005). Low self-esteem is related to aggression, antisocial behavior, and delinquency. Psychological science, 16(4), 328-335.

Endresen, I. M., \& Olweus, D. (2005). Participation in power sports and antisocial involvement in preadolescent and adolescent boys. Journal of child Psychology and Psychiatry, 46(5), 468-478.

Eron, L.D. (1994). Theories of Aggression. In Huesmann L.R. (Ed.) Aggressive Behavior. The Plenum Series in Social/ Clinical Psychology (pp. 3-11). Boston, MA: Springer.

Field, A. (2013). Discovering statistics using IBM SPSS Statistics (4th ed.). Los Angeles: Sage.

Fite, P., Raine, A., Stouthamer-Loeber, M., Loeber, R., \& Pardini, D. (2010). Reactive and proactive aggression in adolescent males: Examining differential outcomes 10 years later in early adulthood. Criminal Justice and Behavior, 37(2), 141157.

Gano-Overway, L. A., Newton, M., Magyar, T. M., Fry, M. D., Kim, M. S., \& Guivernau, M. R. (2009). Influence of caring youth sport contexts on efficacy-related beliefs and social behaviours. Developmental psychology, 45(2), 329.

Geen, R. G., \& Quanty, M. B. (1977). The catharsis of aggression: An evaluation of a hypothesis. In Advances in experimental social psychology (Vol. 10, pp. 1-37). New York: Academic Press.

Gotwals, J. K., Dunn, J. G., \& Wayment, H. A. (2003). An examination of perfectionism and self-esteem in intercollegiate athletes. Journal of Sport Behavior, 26(1), 17-38.

Green, S. B. (1991). How many subjects does it take to do a regression analysis. Multivariate Behavioral Research, 26(3), 499-510.

Gross, J.J., \& John, O.P. (2003). Individual differences in two emotion regulation processes: Implications for affect, relationships, and well-being. Journal of Personality and Social Psychology, 85, 348-362.

Gümüşdağ, H. (2013). The influence of trait and state competitive anxiety on aggression: A study on professional football players. International Journal of Academic Research, 5(3), 188-192.

Hoaglin, D. C., Iglewicz, B., \& Tukey, J. W. (1986). Performance of some resistant rules for outlier labelling. Journal of the American Statistical Association, 81(396), 991-999.

Keeler, L. A. (2007). The Differences in Sport Aggression, Life Aggression, and Life Assertion Among Adult Male and Female Collision, Contact, and Non-Contact Sport Athletes. Journal of Sport Behavior, 30(1) 57-76. 
Huđin, N., Glavaš, D., Pandžić, M. - Contact sports as a sport of more aggressive athletes?

2020. Fakultet za sport i turizam, Novi Sad, Tims.Acta 14, 5-16

Koivula, N., Hassmén, P., \& Fallby, J. (2002). Self-esteem and perfectionism in elite athletes: Effects on competitive anxiety and self-confidence. Personality and individual differences, 32(5), 865-875.

Kotarska, K., Nowak, L., Szark-Eckardt, M., \& Nowak, M. (2019). Selected healthy behaviors and quality of life in people who practice combat sports and martial arts. International journal of environmental research and public health, 16(5), 875 .

Kunimatsu, M. M., \& Mersee, M. A. (2012). Examining the presence of anxiety in aggressive individuals: The illuminating role of fight-or-flight mechanisms. Child \& Youth Care Forum, 47(3), 247-258.

Lane, A. M., \& Lovejoy, D. J. (2001). The effects of exercise on mood changes: the moderating effect of depressed mood. Journal of sports medicine and physical fitness, 41(4), 539-545.

Lane, A. M., Beedie, C. J., Jones, M. V., Uphill, M., \& Devonport, T. J. (2012). The BASES expert statement on emotion regulation in sport. Journal of Sports Sciences, 30(11), 1189-1195.

Lemieux, P., McKelvie, S. J., \& Stout, D. (2002). Self-reported hostile aggression in contact athletes, no contact athletes and non-athletes. Athletic Insight, 4(3), 42-56

Lyras, A., \& Peachey, J. W. (2011). Integrating sport-fordevelopment theory and praxis. Sport management review, 14(4), 311-326.

Malinauskas, R., \& Akelaitis, A. (2018). The expression of emotional skills among individual and team sports male athletes. Pedagogics, psychology, medical-biological problems of physical training and sports Kharkov: Kharkov National Pedagogical University, 22(2), 62-67.

Malinauskas, R., Dumciene, A., \& Malinauskiene, V. (2014). Perceived characteristics of aggressiveness in male adolescent athletes and nonathletes. Revista de Cercetare si Interventie Sociala, 45(24), 17-30.

Manger, T. A., \& Motta, R. W. (2005). The impact of an exercise program on posttraumatic stress disorder, anxiety, and depression. International Journal of Emergency Mental Health, 7(1), 49-57.

Maxwell, J. P., \& Moores, E. (2007). The development of a short scale measuring aggressiveness and anger in competitive athletes. Psychology of Sport and Exercise, 8(2), 179-193.

Megakli, T., Vlachopoulos, S. P., Thogersen Ntoumani, C., \& Theodorakis, Y. (2017). Impact of aerobic and resistance exercise combination on physical selfperceptions and self esteem in women with obesity with one year follow up. International Journal of Sport and Exercise Psychology, 15(3), 236-257.

Ouyang, Y., Wang, K., Zhang, R. T., Peng, L., Song, G., \& Luo, J. (2019). The influence of sports participation on body image, self-efficacy and self-esteem in college students. Frontiers in psychology, 10(3039), 1-10.

Pačesová, P., \& Šmela, P. (2020). Aggression and anxiety trait level of young male contact and non-contact athletes. Acta Gymnica, 50(1), 9-15.

Patterson, A. H. (1974). Hostility catharsis: A naturalistic quasiexperiment. Proceedings of the Division of Personality and Society Psychology, 1(1), 195-197.
Pelletier, L. G., Rocchi, M. A., Vallerand, R. J., Deci, E. L., \& Ryan, R. M. (2013). Validation of the revised sport motivation scale (SMS-II). Psychology of sport and exercise, 14(3), 329-341.

Reza, A. B. (2012). Comparing the incidence of aggression among student athletes in various sports disciplines at the University of Tiran. Procedia-Social and Behavioral Sciences, 47(2012), 1869-1873.

Rosenberg, M. (1965). Society and the adolescent self-image. Princeton, $\mathrm{NJ}$ : Princeton University Press.

Singer, R. N. (1975). Myths and truths in sports psychology. New York: Harper \& Row.

Skelton, D. L., Glynn, M. A., \& Berta, S. M. (1991). Aggressive behavior as a function of taekwondo ranking. Perceptual and Motor Skills, 72(1), 179-182.

Slutzky, C. B., \& Simpkins, S. D. (2009). The link between children's sport participation and self-esteem: Exploring the mediating role of sport self-concept. Psychology of Sport and Exercise, 10(3), 381-389.

Smith, R. E., Smoll, F. L., Cumming, S. P., \& Grossbard, J. R. (2006). Measurement of multidimensional sport performance anxiety in children and adults: The Sport Anxiety Scale-2. Journal of Sport and Exercise Psychology, 28(4), 479-501.

Standage, M., \& Gillison, F. (2007). Students' motivational responses toward school physical education and their relationship to general self esteem and health related quality of life. Psychology of Sport and Exercise, 8(5) 704721.

Szuhany, K. L., Bugatti, M., \& Otto, M. W. (2015). A metaanalytic review of the effects of exercise on brain-derived neurotrophic factor. Journal of psychiatric research, 60, 5664.

Trivedi, R., \& Pinto, E. (2015). A comparative study of aggression between contact game and non-contact game players of Maharashtra. Int. J. Phys. Educ. Sports Health, 2(2), 137140.

Trulson, M. E. (1986). Martial arts training: A novel "cure" for juvenile delinquency. Human Relations, 39(12), 1131-1140.

Visek, A. J., Watson, J. C., Hurst, J. R., Maxwell, J. P., \& Harris, B. S. (2010). Athletic identity and aggressiveness: A cross cultural analysis of the athletic identity maintenance model. International Journal of Sport and Exercise Psychology, 8(2), 99-116.

Zillmann, D., Johnson, R. C., \& Day, K. D. (1974). Provoked and unprovoked aggressiveness in athletes. Journal of Research in Personality, 8(2), 139-152.

Datum prijave: 01. 07. 2020.

Datum prihvatanja: 17.07.2020. 
Huđin, N., Glavaš, D., Pandžić, M. - Contact sports as a sport of more aggressive athletes? 2020. Fakultet za sport i turizam, Novi Sad, Tims.Acta 14, 5-16

\section{Kontakt}

Nikolina Huđin, Umjetnička udruga "Korak",

Zagreb, Hrvatska, Vladimira Filakovca 14

E-mail: nikolina1509@gmail.com

Dragan Glavaš, Hrvatsko katoličko sveučilište,

Zagreb, Hrvatska, llica 242

E-mail: dragan.glavas@unicath.hr

Mario Pandžić, Hrvatsko katoličko sveučilište,

Zagreb, Hrvatska, llica 242

E-mail: mario.pandzic@unicath.hr 